\title{
Landscape and Reality in Apuleius' Metamorphoses
}

\author{
JASON KÖNIG \\ University of St Andrews
}

\section{Introduction}

Apuleius' Metamorphoses invites its readers - more conspicuously so than any of the other surviving ancient novels - to reflect on the possibility that mortal understandings of 'reality' are inadequate. One of the major themes of the work is the way in which the validity of Lucius' perceptions of the world around him, in Books 1-10, is thrown into doubt by his access to higher, divine knowledge in Book 11 (although the work of course also leaves open the possibility that Lucius' judgement in Book 11 is just as flawed as it always had been). ${ }^{1}$ In that sense, reading Apuleius takes us right to the heart of the concerns of this volume.

My argument in this paper is that the work's representation of landscape - and especially mountainous landscape - plays a key role in Apuleius' exploration of that theme. I aim to show that Apuleius' landscapes are characterised by two different strands. The first is a strikingly rhetorical conception of landscape. The Metamorphoses is full of stylised, mirage-like terrains, which draw heavily on recognised literary and rhetorical motifs. Apuleius, I suggest, goes out of his way to expose the inadequate, fabricated, unreal character of those representations. In my second section I draw attention to a rather different strand in Apuleius' narrative, that is its obsessive sense of the physical presence of landscape and the way in which landscape impinges on the

\footnotetext{
${ }^{1}$ My subject in what follows is the difference between Book 11 and what comes before, rather than the (important) satirical elements of Book 11, but that should not be taken to imply that I read the work as straightforwardly didactic or protreptic: cf. Shumate 1996, esp. 7, 13-14 and 325-328 on the Metamorphoses as 'simultaneously a satire of credulity and a seductive evocation of religious belief' (7).
} 
human (or asinine) body. This strand of description at first sight looks diametrically opposed to the rhetorical strand I have just outlined. Nevertheless I aim to show here that it ultimately turns out to be just as inadequate: both of these ways of perceiving physical space turn out to be signs of Lucius' subjection to the sublunary world in Books 1-10; both are rejected in favour of what the narrator represents as the higher realities of Isis in Book 11 (which is the subject of the third and final section of this chapter). The destruction of the stageset mountain at the very end of Book 10 stands, I will argue, as an emblem of the novel's rejection of Lucius' flawed, pre-Isis experience of landscape in all that has come before.

In all of these senses Apuleius' depiction of landscape is highly complex and self-conscious. In some ways it is even surprisingly modern. Admittedly Apuleius' obsession with mountains as places of fear and danger is entirely typical of classical and other pre-modern writing. The idea of mountains as places of beauty and sublimity, to be climbed and admired, is a surprisingly modern one: it is now commonplace to claim that these notions have become widespread only in the last two hundred years or so. ${ }^{2}$ In other respects, however, Apuleius' landscape depictions have a sophistication which goes beyond what we find in most other classical texts. Perhaps most importantly, the Metamorphoses offers a striking counter-example to the idea that pre-modern writing on landscape, mountainous landscape in particular, is characterised by an unthinking adherence to allegorical or conventionally rhetorical portrayal: ${ }^{3}$ Apuleius does indeed use rhetorical and poetic stereotypes of landscape description, as I have suggested, but he also self-consciously demonstrates their inadequacy, sweeping them away from view with the stage-set mountain of Book 10. One might point also to Apuleius' concern with the corporeality of landscape - the second of my two strands outlined above. The frequency with which Apuleius returns to that theme is hard to parallel in other surviving classical literature. It also has striking resonances with phenomenological approaches to landscape in recent scholarship, which often shows a similar interest in the tactile or 'haptic' character of landscape - in other words the way in which it impinges on our sense of touch and contributes to our own bodily experience of movement through the world. ${ }^{4}$ Finally, the two different strands of landscape perception I have drawn attention to in the Metamorphoses correspond roughly with the two different ways of conceiving landscape which have lain at the heart of writing in cultural geography in recent decades: on

\footnotetext{
2 See Nicholson 1959, 38-42; MacFarlane 2003, esp. 137-167.

${ }^{3}$ See Nicholson 1959, esp. 34-71.

${ }^{4}$ See Wylie 2007, 166-169.
} 
the one hand landscape as symbol or construct; on the other hand landscape as lived, material reality. A large proportion of recent work within the discipline of cultural geography debates the relative merits of those two different models. ${ }^{5}$ Not only does Apuleius show some awareness of those two alternative conceptions, he also takes the further step of suggesting that they are ultimately compatible with each other, and equally inadequate, in the sense that both of them are associated with the sublunary world of human perception which Lucius claims (whether or not we believe him) to have discarded at the beginning of Book 11.

\section{Fantasy Landscapes}

How then does Apuleius characterise the extraordinary landscapes Lucius moves through in his travels? Their most striking feature is simply their remarkable prominence within the narrative. The Metamorphoses is packed with mountains - rocks, peaks and precipices, many of them dangerous and threatening, marked out by imagery of steepness and roughness and jaggedness. Those passages alternate with more welcoming landscapes - valleys and plains, streams and meadows. ${ }^{6}$ The landscapes of the work are also often fantastical, fabricated, mirage-like (an effect which is enhanced by the geographical imprecision of the central books of the novel). ${ }^{7}$ That quality is the main subject of this section. Lucian's immersion in these fantastical landscapes goes hand in hand with his imprisonment in a new body and a new identity. Some aspects of the artificiality of the work's landscapes have been well discussed in recent scholarship. For one thing, Apuleius' landscapes often have allegorical connotations. Maaike Zimmerman has shown that these become increasingly important as the Metamorphoses goes on, although she rightly avoids suggesting that they articulate any simplistic message, seeing instead a playfully imprecise engagement with allegorical and moralising language. ${ }^{8}$

${ }^{5}$ See Wylie 2007, 1-16.

${ }^{6}$ For surveys of Apuleius' depiction of landscape see de Biasi 1990; Krabbe 2003, 90-121.

${ }^{7}$ Millar 1981 (cf. Fick 1991) has rightly discussed the realistic quality of Apuleius' depiction of Roman provincial life in some parts of the text. However, that realism is in tension with ostentatiously unrealistic and stylised pictures of wild landscape elsewhere in the novel, which are disorientatingly cut free from any kind of topographical markers: see Zimmerman 2000, 11; Slater 2002, 173. The Onos, by contrast, is much more precise about topography: see Graverini 2002, esp. 58-59.

${ }^{8}$ Zimmerman 2002, esp. 91-96 (with reference to the Hesiodic distinction between the hard road to virtue and the easy way to vice: Works and Days 287-291); cf. Bakhtin 1981, 120; 
There has also been a great deal of work on the allusive, literary character of the novel's landscapes, and (closely related to that) the way in which they draw on rhetorical traditions of ekphrastic landscape description. ${ }^{9}$ Much of that literary-rhetorical embellishment seems to have been Apuleius' innovation, rather than something taken from his Greek source, given that it is not present in any sustained form within the Onos. ${ }^{10}$ It is important to stress, of course, that ekphrasis is not always automatically associated with artificiality. Ancient theories of ekphrasis - by which I mean the practice of producing enargeia or clarity, in Greek rhetorical theory - view it as a technique which aims to bring to life the scene being described, making absent things present. ${ }^{11}$ However, there is also a strong strand within these ancient discussions, which acknowledges the gap between the fabricated scene and the original on which it is based, ${ }^{12}$ and Apuleius is clearly aware of that (as we shall see below in looking at his description of the bandits' lair at 4,6). ${ }^{13}$

That recent scholarship on the literary and rhetorical texture of the novel's terrains has greatly enhanced our detailed understanding of particular passages. However, there has been a general failure to acknowledge the fact that these effects go well beyond literary game playing. It is not simply that Apuleius sometimes chooses to break the illusion of narrative - winking, as it were, at his audience. In addition, I suggest, this acute awareness of artificial landscape keys into the wider theme of false perception which is so important for the work as a whole, and which comes to a head at the moment of transition between Books 10 and 11. In Book 11, everything changes. From now on, so the narrator suggests, that immersion in the world of the senses and the body, which has preoccupied Lucius and us as readers so intensely, will be replaced by the higher realities of Isis. ${ }^{14}$ Maeve O'Brien has argued that this distinction

also Elsner and Rubiés 1999, 8-15 on travel as a metaphor for the journey to spiritual enlightenment in the Neoplatonic (and later, Christian) writing of the later Roman Empire.

${ }^{9}$ See esp. below on Met. 4,6; also de Biasi 1990, 248-253 on landscape in Apuleius' Florida (esp. Florida 1, 10,4, 11 and 21).

${ }^{10}$ Most of the passages I discuss from the Metamorphoses in this chapter have no close equivalent in the Onos; all exceptions are noted.

${ }^{11}$ See Webb 2009, esp. 87-106.

${ }^{12}$ See Webb 2009, 167-191.

${ }^{13}$ See Shumate 1996, 67-71 on the links between ekphrasis and artificiality in the work.

${ }^{14}$ Admittedly, that argument is complicated by the fact that the narrating voice has several different layers. In many passages in Books 1-10 we look at landscape through Lucius' eyes as he experienced it at the time: see Zimmerman 2002, esp. 81-86 and 95. In other cases, however, particularly in some of the lengthier passages of ekphrasis, we seem to be hearing the voice of the narrator speaking with hindsight, showing off his rhetorical skills: see Paschalis 2002 on 2,4, with reference also to 4,6, 5,1, 6,14 and 10,32-3; also van Mal- 
between the mortal and divine realms is crucial to the Metamorphoses. ${ }^{15}$ She suggests, with particular reference to Apuleius' work De Platone, ${ }^{16}$ that Apuleius draws on Plato - especially the Gorgias and the Phaedrus - in order to set up a contrast between two types of discourse: the sublunary, earthly discourse of Books 1-10, which is concerned above all with trickery and appearance, associated with things which are literally visible in the world of senses; and the higher discourse of Book 11, which can give access to higher truths, and portrays things which are visible to the mind's eye. From a slightly different perspective, Nancy Shumate has explored at length the way in which the Metamorphoses parallels other ancient (and also modern) conversion narratives where conversion is preceded by an impression of disintegrating reality. She explains that 'according to this pattern of crisis and conversion, a perception of the collapse of familiar cognitive constructs precedes the convert's reconstruction of a new world and world view along religious lines' ${ }^{17}$ And she shows how Books 1-4 in particular are full of a sense of the unstable and untrustworthy character of the physical world as Lucius perceives it. ${ }^{18}$

The very opening sentences of Lucius' narrative fit in with the pattern of rhetorical landscape description. He tells us first of all that he was travelling to Thessaly on business. Then in the second sentence of 1,2 we find the following:

After I had emerged from the steep paths of the mountains (ardua montium) and the slippery paths of the valleys and the wet paths through the meadows and the cloddy paths of the fields, riding on a native white horse, because he too was very tired, and in order that I might also myself shake off my saddle-soreness by the invigorating act of walking, I jumped down to my feet, attentively rubbed away the sweat from my horse's forehead, caressed his ears, detached his bridle, and led him forward at a gentle pace,

\footnotetext{
Maeder 1997a. That need not mean, however, that we should see these ekphrasis scenes as irrelevant to Lucius' perception of the world at the time. In practice it is often difficult to separate actor and auctor securely (cf. below on 4,6). We might anyway feel that the narrator is trying to reproduce for us, through these set-piece passages of rhetorical description, the world of false perceptions which his own former self had moved through. Alternatively - and more unsettlingly - we might even take this as a sign that he is still mired in that world of false rhetoric, and keen to indulge in it even after his conversion in Book 11 .

${ }^{15}$ O’Brien 2002.

${ }^{16}$ O'Brien 2002, 10-15.

17 Shumate 1996, 14.

${ }^{18}$ Shumate 1996, 43-90.
} 
until the accustomed and natural operations of his stomach removed the discomfort of his weariness. (Met. 1,2,2)

The opening group of four phrases - 'steep paths ... slippery paths ... wet paths ... cloddy paths' - is carefully crafted. It draws heavily on epic language ${ }^{19}$ it also has a heavily rhetorical feel, as if ticking off in turn the different categories of landscape description one might use in a rhetorical exercise. ${ }^{20}$ Lucius is offering, in other words, an elevated and idealised vision of his own travel. It is striking, however, that the air of detachment and even idealisation or aggrandisement implied by the first half of the sentence is not maintained. Most obviously, anyone coming to this passage as a second reader will know that Lucius is about to have a more brutal set of confrontations with the ardua montium than he is bargaining for here (as we shall see further in the next section). ${ }^{21}$ Even within this opening sentence there is a move from elevated language downwards to very mundane, physical concerns - the wiping of the sweat, the horse's digestion problems. ${ }^{22}$ Here then, in the very opening section of the narrative, Apuleius presents us with a rhetorical vision of landscape while also signalling its inadequacy as a representation of the real, bodily experience of travelling: Lucius is quite literally brought down to earth as the sentence goes on. In addition, the word 'emerged' (emersi) perhaps even anticipates Lucius' final emergence from the oppressive world of rocky slopes, slippery paths and false perceptions which has held him in its grip throughout Books 1-10. ${ }^{23}$

That passage is followed, in Books 1 and 2, by Lucius' first impressions of the town of Hypata. Here the text repeatedly returns to the image of landscapes which are formed or altered by magic. Landscape, on that account, is malleable, open to fabrication, untrustworthy. In 2,1, the most prominent of several examples,${ }^{24}$ Lucius speaks as follows:

Nothing of what I saw in that city seemed to me to be what it was, but everything had been completely transformed into another shape by deadly muttering; the result was that I believed that the stones I stumbled over were hardened humans, that the birds I heard were feathered humans, that

\footnotetext{
${ }^{19}$ See Keulen 2007, 97-100.

${ }^{20}$ See de Biasi 1990, 201-202; Merlier-Espenel 1999, 163-164; Zimmerman 2002, 79-80; also Keulen 2007, 96 on overlaps with Florida 21,3.

${ }^{21}$ See Krabbe 2003, 92.

${ }^{22}$ See Keulen 2007, 96-97 and 100-104.

${ }^{23}$ Cf. Krabbe 2003, 109-110.

${ }^{24}$ Other key passages include $1,3,1,1,8,4,2,5,4-7$.
} 
the trees which ran around the city wall were in the same way foliated humans, and that the waters of the fountains were liquefied human bodies. $(2,1,3-4)$

That sentence - and especially the phrase "nothing seemed to me to be what it was' - foregrounds the theme of untrustworthy perception. ${ }^{25}$ Here we clearly are seeing events through Lucius' eyes as he experienced them at the time. ${ }^{26}$ The surface appearance of the city's landscape, in Lucius' view, is not reliable; it hides behind it a sinister, magical reality. Equally Lucius' own perception of the ubiquity of magic seems suspect in itself: this is a highly literary landscape, imbued with precedents from Ovid's Metamorphoses and elsewhere, as if Lucius has read Ovid too literal-mindedly and fabricated a vision of the landscape of Hypata on that basis. ${ }^{27}$

The link between landscape and fabrication or false perception becomes even more prominent after Lucius' transformation. There are, for example, several scenes which use the poetic conventions of the locus amoenus to describe apparently idyllic landscapes which later turn out to be deceptive and dangerous. ${ }^{28}$ The most striking example comes very soon after Lucius' transformation. Having been led away from his host's house in Hypata by the robbers in 3,28 he is convinced that he has found roses, the antidote to his metamorphosis:

a little further off I saw a glen full of the shade of a leafy wood; and in the middle of its various little plants and luxuriant shrubs, shone the bright red colour of gleaming roses. And now in my heart, which was not wholly bestial, I thought that it was a grove of Venus and the Graces, within whose dark recesses the royal splendour of this festive flower was gleaming $(4,2,1-2)$.

His hopes are dashed. The flowers turn out to be not roses but oleanders, which are poisonous. Lucius resolves to eat them anyway, but at that moment the gardener and several others approach him and begin to beat him. The locus amoenus - marked as such among other things by the association with Venus and by the imagined presence of the rose, the archetypal flower of such spaces

\footnotetext{
${ }^{25}$ See van Mal-Maeder 2001, 58-61; Shumate 1996, 50 and 60-61.

${ }^{26}$ See Paschalis 2002, 138-139.

${ }^{27}$ For that suggestion, see Penwill 1990, 8; cf. Shumate 1996, 56-60; van Mal-Maeder 2001, 59.

${ }^{28}$ See Merlier-Espenel 1999; Mattiacci 2001.
} 
- turns out to be a mirage, a place of violence and threat, populated by a much more mundane flower, which is described by the narrating Lucius in pointedly realistic, almost scientific terms. ${ }^{29}$ There are several other similar examples of false locus amoenus scenes in the work. ${ }^{30}$

That theme of fabricated, fantasy landscape is treated in more extended form in a number of passages in the work which draw on traditions of ekphrasis. The first and lengthiest of these - and the one which has received most critical attention - comes early in 4,6, where we hear a description of the bandits' mountain hideout:

The subject and occasion demand that I should offer a description of the region and the cave which the robbers inhabited. For I shall at the same time put my abilities to the test and also make sure that you gain a clear insight into the question of whether I really was a donkey in my understanding and my faculties of perception. The mountain was rough, shady with forest foliage and exceptionally high. Its very steep slopes, where it was surrounded by jagged and hence inaccessible rocks, were encircled by hollow, pitted valleys... From the highest peak a spring gushed down abounding in giant bubbles, and pouring down the steep sides, it vomited out silvery waves... $(4,6,1-4)$

The first thing that stands out here is simply the elaborately crafted nature of this description. The rhetorical character of the description is enhanced by the apostrophe to the reader, a common feature of ekphrasis, which draws attention to the way in which the scene is being brought to life in front of our eyes. ${ }^{31}$ We seem to be hearing here the voice of the post-conversion narrator, especially when he informs us that he wishes to use the description as a display of his talent (ingenium). That said, Apuleius also makes it clear, in his desire to let the reader know 'whether I really was a donkey in my understanding and my faculties of perception' $(4,6,2)$, that the description has at least some connection with Lucius' pre-conversion view of the world, being based on the details he stored away in his mind at the time. ${ }^{32}$ The literary quality of the

${ }^{29}$ See Mattiacci 2001, 853-858, who shows that Apuleius' version involves a much more complex play with locus amoenus conventions than the equivalent scene in Onos 17; and cf. Hijmans et al. 1977, 28 f. ad loc.; de Biasi 1990, 216-219.

${ }^{30}$ E.g., see Met. 1,19, with de Biasi 1990, 219-222; Merlier-Espenel 1999, 162-163; Mattiacci 2001, 847-853; also Met. 8,18-19; and Hijmans et al. 1977, 28-29 for a full list.

${ }^{31}$ See Trinquier 1999, 268, esp. n.58.

32 See Trinquier 1999, 270-271; de Jong 2001, 209. 
work is also clear. The language of jaggedness and steepness, which is a recurring feature of the work as a whole, draws heavily on stereotyped poetic language of mountain description. ${ }^{33}$ Moreover, the passage is full of carefully crafted language, packed, for example, with alliteration and assonance. ${ }^{34} \mathrm{~A}$ number of scholars have seen this as a key passage in the history of locus horridus traditions in Latin poetry, pointing out how Lucius systematically inverts the motifs of the locus amoenus in Virgil and Seneca and others. ${ }^{35} \mathrm{In}$ addition, the passage has a historiographical character: for example the opening phrase - 'the subject and occasion itself demand' - echoes a number of passages of Sallust and Tacitus. ${ }^{36}$

Not only that, but it is also clear on closer inspection that the passage has a strong air of exaggeration and inconsistency and absurdity, and that Apuleius goes out of his way here to draw attention to the artificiality of the description. ${ }^{37}$ For one thing, the jaggedness of the hideout as it is described here contradicts Lucius' account of their arrival at the hideout just a few lines before: 'we then climbed a gentle slope and arrived at our destination' $(4,5,7) .{ }^{38}$ The grand, imposing quality of the passage - appropriate to epic or historiography - is undermined by a final bucolic detail, just after the passage quoted above, where we hear that the mountain was topped with a 'tiny hut carelessly thatched with cane', which recalls the hut of Philemon and Baucis in Ovid, Metamorphoses 8,629-630 or the hut in Ps.-Virgil's Moretum 60-61 and 66. ${ }^{39}$ And the passage's historiographical pretensions have an obvious absurdity when we note the incongruity between the serious tone and the identity of Lucius, at the time of gathering his material, as a donkey. ${ }^{40}$ That seriousness is further undermined when we take account of a passage from Lucian's $O n$ How to Write History 19-20, which is critical of those who pad their histories out with excessively long landscape descriptions of precisely this kind. ${ }^{41}$ All of those factors contribute to the impression of a fantasy mountain, almost a cardboard cut-out, patched together rather inconsistently from conventional rhetorical and poetic motifs.

\footnotetext{
${ }^{33}$ See Krabbe 2003, 93 for a good example.

${ }^{34}$ See de Biasi 1990, 210-214.

${ }^{35}$ See Schiesaro 1985, esp. 214-219.

${ }^{36}$ See Walsh 1970, 57-58; Schiesaro 1985, 215; Trinquier 1999, 267.

${ }^{37}$ See Keuls 1974, 267; de Biasi 1990, 215; Trinquier 1999, 269-276; Mattiacci 2001, 845846.

${ }^{38}$ See Keuls 1974, 267.

${ }^{39}$ See Trinquier 1999, 271-272.

${ }^{40}$ See Trinquier 1999, 270-271.

${ }^{41}$ See Keuls 1974, 266-267; Schiesaro 1985, 214-215; Trinquier 1999, 269-270.
} 


\section{Landscape and the Body}

Landscape, then, is consistently linked with fabrication and false perception in Books 1-10 of the Metamorphoses. In parallel with that theme, however, there is another prominent strand of landscape description - standing in contrast to the unrealistic, stylised character of the scenes I have been discussing so far - which stresses the physicality of landscape, and its ability to impinge on human and asinine bodies in ways which produce suffering. ${ }^{42}$ Maaike Zimmerman, among others, has shown how Lucius' landscape descriptions often reflect his own perception of the situation in which he finds himself. ${ }^{43}$ She focuses, however, on the mental rather than the bodily impact of the roads Lucius travels along. That bodily impact seems to me to be one of the things which makes Apuleius' description of travel so memorable. Admittedly some aspects of this interest in the physicality of landscape are present in the Onos, as part of that work's obsession with the harshness and brutality of lower-class life. ${ }^{44}$ But it is also clear that Apuleius has very much extended those themes in his own version. Admittedly, too, some of the motifs I discuss in this section can be paralleled elsewhere in surviving classical literature. However, the sheer frequency with which they recur in the Metamorphoses is, I suggest, quite remarkable. One function of that sense of the physicality of landscape is to debunk the unrealistic, idealised, rhetorical versions of landscape I have so far been discussing. At the same time, however, it draws attention to another aspect of the limitation of Lucius' understanding of the world, standing as a

${ }^{42}$ For reasons of space it has not been possible to give close attention here to the remarkable landscapes of the Cupid and Psyche story, but it should be clear at once that they fit in with many of the patterns I have been discussing. Psyche encounters landscapes which are highly literary and stylised: e.g., see Harrison 2002, 48-52 for their literary character; and on locus horridus stereotypes in the cliff of 6,14,2-4, and its close links to the earlier description of the robber's cave, see Schiesaro 1985, 211-212 and 219-222; de Biasi 1990, 229-230; Merlier-Espenel 1999, 165-167. At the same time they are brutally physical landscapes (see further examples later in this section). Those themes play a key role in the work's depiction of Psyche's immersion in the realm of earthly experience: see Kenney 1990, esp. 184-185, Edwards 1992 and Harrison 2000, 256-258 on the Platonic distinction between spiritual and earthly in the famous scene in Metamorphoses 5,24 where Psyche falls back to earth. In all of those respects, Psyche parallels Lucius: see Frangoulidis 2008, 120-124 on general parallels between Cupid and Psyche; also 6,13,4 and 6,16-20, with Harrison 2002, 51-52, for Psyche's encounters with infernal landscape, which parallel the repeated use of infernal imagery for the landscapes Lucius moves through (on which see Nethercut 1969, esp. 101, 103-104 and O'Brien 2002, esp. 32-35 and 104, n. 53).

${ }^{43}$ See Zimmerman 2002, esp. 81-86 and 95; cf. Bakhtin 1981, 120; de Biasi 1990.

${ }^{44}$ See Hall 1995. 
sign of his earthliness, and his inability to see beyond bodily experience to higher spiritual truths.

The most straightforward manifestation of that theme, and the one where Apuleius is closest to the Onos, comes in the many scenes where Lucius is concerned about the way in which the landscape digs into his feet as he walks, or otherwise impedes his progress. There is a cluster of these scenes in Book 9. In 9,9, for example, Lucius describes his journey with the false priests:

the road was pitted with puddle-filled channels, wet in places with stagnant swamp-water, and in other places slippery with filthy slime. In addition, my legs were battered by frequent obstacles and continual slipping... $(9,9,1-2)$

In 9,10,5, having passed into the ownership of a baker, Lucius is having trouble with his feet again: 'Immediately ... he led me along a steep path which was threateningly full of sharp stones and bushes of every kind, to the mill which he ran'. ${ }^{45}$ And in 9,32,4, winter brings a particularly unpleasant version of the same problem: 'In the morning, stepping with my naked feet on the freezing mud and the extra-sharp fragments of ice, I was tormented to death' ${ }^{46}$

An even more brutal version of this kind of encounter with rocky landscapes comes in the many scenes where people are attacked and often killed with rocks. In 4,27,4, for example, the girl who is being held by the robbers in their hideout explains that she has dreamt of her new husband being killed: 'one of the robbers, provoked to a state of fury at his relentless pursuit, having grabbed a stone which lay at his feet, struck my poor young husband and killed him'. In 8,17 Lucius and those he is travelling with suddenly find themselves under attack for no apparent reason, in a scene which replays Odysseus' encounter with the stone-throwing Laestrygonians in Odyssey Book 10: 'For from the rooftops and from the nearest hill those farmers quickly rolled down rocks on top of us ... In fact, one of the stones suddenly smashed against the head of the woman who was sitting on my back' $(8,17,4-5)$. And in 9,40, Lucius' owner attacks a Roman soldier who has accosted him on the road: 'immediately he began to pound him on his face and his hands and his sides, with his fists, his elbows, his teeth, even with a rock grabbed from the road' $(9,40,2) \cdot{ }^{47}$

\footnotetext{
${ }^{45}$ Onos 42 mentions only a 'hard road'.

${ }^{46}$ Cf. Onos 43.

${ }^{47}$ Cf. Onos 44.
} 
Most horrifyingly of all, there is a succession of scenes in the central books set in the robbers' hideout where individuals are thrown over cliffs to die on the rocks beneath, or else are threatened with that fate. In 4,5, one of Lucius' fellow donkeys is thrown over a cliff 'even now still breathing, off a very high precipice down into the next valley' $(4,5,4)$ as punishment for collapsing out of exhaustion, moments after Lucius had contemplated doing the same. ${ }^{48}$ Here, the physical impact of landscape is made horrifyingly clear, although it is important to stress that even at such a moment of physical brutality Apuleius is reluctant to abandon a rhetorical style of presentation: these phrases have a highly crafted, alliterative character. ${ }^{49}$ In 4,12 , some of the newly returned robbers give an account of the death of one of their comrades, Alcimus, who was pushed out of a window by an old woman: 'quite apart from the great altitude, he fell on top of an enormous rock which was lying nearby, and his ribcage was shattered and scattered' $(4,12,8)$. One of Psyche's sisters, in the story Lucius listens to in the hideout, dies by being dashed on the rocks after jumping off the cliff without the help of Zephyr: 'her limbs were tossed and scattered by the rocks of the cliff' $(5,27,3)$; her other sister meets with the same fate not long afterwards $(5,27,5)$. In 6,25 , Lucius is taken out to collect some stolen goods which have been stashed in a cave and collapses with exhaustion: 'battering me and shoving me with frequent blows they made me fall on top of a rock at the side of the road' $(6,25,4)$. When they return to the hideout they threaten to dispose of him, given his weakness, by throwing him over a cliff, ${ }^{50}$ and he contemplates his fate in a soliloquy: ${ }^{51}$ 'Do you see those nearby ravines and the sharp rocks which stick out into them, which will penetrate you before you reach the bottom and rip you apart limb by limb?' $(6,26,6)$. Ironically that is precisely the fate that awaits many of the robbers themselves after their capture in 7,13,6. ${ }^{52}$ The Metamorphoses, then, has an obsessive and gruesome fascination with the extreme vulnerability of human and asinine bodies to the physicality of landscape. That fascination has, to my knowledge, never received any sustained critical attention. ${ }^{53}$

\footnotetext{
${ }^{48}$ Cf. Onos 19.

${ }^{49}$ See de Biasi 1990, 236-237; and cf. similar comments at 230 on 6,26, discussed later in this paragraph.

${ }^{50}$ Cf. Onos 22.

${ }^{51} \mathrm{Cf}$. Onos 23 for a much briefer version.

${ }^{52}$ In Onos 26, by contrast, the bandits are tied up and led away to the governor.

${ }^{53}$ However, see brief discussion of rocky deaths in Nethercut 1969, 105-106 and Smith 1998, 72-73.
} 
One particularly outlandish manifestation of those concerns is in the many scenes where Apuleius presents us with bodies which are immured in the landscape or trapped by it, so as almost to become a part of it. Lucius' perception of the magical quality of the landscape of Hypata, quoted above, is a good example from early in the work: 'I believed that the stones I stumbled over were hardened humans...' $(2,1,4)$. In 2,5,7, similarly, Lucius is warned about the magical powers of his wife's host, who transforms her lovers 'instantly into rocks or sheep or any other sort of animal' if they offend her. In 8,22, a particularly horrifying example, Lucius hears a report of a terrible punishment inflicted on a slave who is covered in honey and tied to a tree so as to be devoured by ants: 'after a long period of torture the man died, with his flesh and even his innards eaten away, and they denuded his limbs so that only the bones remained, deprived of meat and shining with great brightness, and still clinging to that fatal tree' $(8,22,7)$. The slave's body stands as a part of the landscape after his death. Metaphorical petrification also recurs often in the work. In 6,14,6, for example, Psyche, overwhelmed by the terrors of the inaccessible cliff from which she has been instructed to fetch water, is 'turned into stone by the impossibility of it', becoming almost a part of the landscape she fears. And in 4,5,3, mentioned already above, the exhausted donkey is described in similar terms: the robbers agree among themselves 'not to delay their flight too long for the sake of a dead, or rather petrified, donkey', as if he has already become a part of the jagged mountain landscape in which he is about to meet his death. There are even hints that Lucius himself envisages his metamorphosis as a process which has similarities with this experience of being absorbed or entrapped by landscape.$^{54}$ In 3,23 he expresses his desire to take to the air as an owl, but his transformation into a donkey in 3,24 keeps him firmly tied to the earth. ${ }^{55} \mathrm{He}$ is acutely aware of the coarseness of his new body: 'my hair was thickening into bristles and my delicate skin was hardening into hide (duratur in corium)' $(3,24,4)$. That word 'duratur' echoes the similar phrase used in 2,1,4 to describe 'rocks transformed (literally 'hardened') from men' (lapides ... de homine duratos). The similarity between these passages stands out all the more given that this usage of durare to describe metamorphosis is unique to Apuleius in surviving Latin. ${ }^{56}$

For one final illustration I want to turn finally now to the episode in Book 7 which follows Lucius' liberation from the bandits' hideout. This is a section of the novel where Apuleius' sensitivity to the encounter between body and

\footnotetext{
${ }^{54}$ See also below for even stronger hints in the retransformation scene in 11,13 .

${ }^{55}$ See Frangoulidis 2008, 162.

${ }^{56}$ See van Mal-Maeder 2001, 60.
} 
landscape is particularly acute. We join the action in 7,14, where Lucius is anticipating the rewards he has been promised for helping the girl Charite in her attempted escape from the robbers. He is to be allowed 'to run free in the country fields' $(7,14,5)$ and he is at last happy: 'I was now about to give up loads and burdens, and having gained my freedom was sure to find some roses at the beginning of spring in the flowering meadows' $(7,15,1) .{ }^{57}$ Predictably enough, however, this turns out to be another one of the novel's false locus amoenus scenes, and Lucius is soon plunged back into a nightmare world of discomfort and danger. The wife of the herdsman assigned to look after him, 'a greedy and utterly wicked woman' $(7,15,3)$ attaches Lucius to a mill and puts him to work, driving him mercilessly. The claustrophobia of his endless 'circling steps' (ambagibus) $(7,15,5)$ stands in contrast with the freedom he has anticipated. Not only that, but the harsh, painful, rocky landscapes which have been so much of a torment to him before now infect even Lucius' food: we hear that she used to give him 'bran which was unsifted and dirty and rough with much gravel' (furfures incretos ac sordidos multoque lapide salebrosos) $(7,15,5)$. Not only does the rocky landscape impinge on him painfully from the outside; here it also works his way inside his body through his consumption of the gravel. ${ }^{58}$

There is no relief in view. Soon afterwards, Lucius is assigned to carry wood down from the nearby mountain, and the boy given the task of supervising him turns out to be a monster of cruelty: ${ }^{59}$

Not only was I exhausted by the steep ridge of the high mountain, not only did I wear down my hooves by knocking them against rocky spikes, I was also beaten into shape even on the downward slope by frequent blows from a stick to such an extent that the pain from the blows penetrated even into the marrow of my bones. By always striking his blows against my right hip, and always hitting the same place, he wore away the hide and inflicted on me a very wide wound, making a hole - or rather a pit or even a window (immo fovea vel etiam fenestra). (7,17,3-4)

The mountain vocabulary here is entirely familiar by this stage to anyone who has read the rest of the novel - the steep slopes and spiky rocks, which trip

${ }^{57} \mathrm{Cf}$. Onos 27, but with no locus amoenus imagery and no mention of roses.

${ }^{58} \mathrm{Cf}$. 9,32,4, where he eats lettuce which has rotted into a 'bitter mess of muddy juice' (amaram caenosi sucus cariem).

${ }^{59}$ Much of the material discussed in this paragraph is close to Onos 29-31, although some of Apuleius' most memorable phrases (e.g. the image of the 'pit or window' in 7,17,4 or the description of the bank 'slippery with muddy slime' in $7,18,8$ ) have no equivalent there. 
Lucius and dig into him. What makes this passage stand out is the extraordinary description of the pit in his skin: the physical impact of Lucius' enslavement is so extreme that his body almost becomes a landscape, to be dug up and hollowed out. Worse is to come. Whenever Lucius' load becomes unbalanced the boy evens out the load by adding stones rather than moving sticks from one side to the other $(7,17,5)$ : Lucius is being pressed down by rocks from above as well as tormented by them underfoot. Moreover, the boy offers him no help 'if by some chance, where the edge of the bank was slippery with muddy slime (limo caenoso), I collapsed because of my inability to bear my burden and slid down' $(7,18,2)$. In 7,20, finally, the boy sets fire to Lucius and he has to throw himself into a 'puddle of muddy water' $(7,20,2)$, coating his body in grime in order to save himself. ${ }^{60}$

On one level this attention to the suffering of the body in its encounter with landscape is ostentatiously 'realistic'. It is a sign that Lucius undergoes a very visceral confrontation with the 'real world'. In that sense it debunks the 'false rhetoric' of the idealised, stereotyped landscape scenes laid out in the previous section. At the same time, however, it also reveals other limitations in Lucius' viewpoint. Most importantly it reminds us of the fact that he inhabits a world where bodily concerns are so overwhelming that it is hard to see beyond them to higher spiritual truths. ${ }^{61}$ This is another rather different aspect of the 'earthliness' of Books 1-10 discussed in the previous section.

Moreover, the theme of the body's confrontation with landscape also contributes to the impression of Lucius as a figure who is disoriented and confused, forced by his new situation to experience the world in ways which are alien to him. There has been a tendency in ancient novel scholarship to categorise Apuleius' Metamorphoses, along with Petronius' Satyrica and some of the Greek fragments, as a 'comic-realistic' novel, in contrast with the more idealised Greek novel tradition. ${ }^{62}$ That is partly, and justifiably, because of Apuleius' interest in portraying, in some respects very convincingly, the experience of non-elite life in Roman Achaia. ${ }^{63}$ It is also, however, due in part to the novel's obsession with grotesque physicality. In practice, however, close attention to the physical working of the human body and to the grotesque

${ }^{60}$ Cf. 4,5,7, where Lucius rolls in dust, for a more pleasurable version of the image of voluntary immersion in landscape.

${ }^{61}$ On the prominence of bodily concerns in Books 1-10 see (among others) Schlam 1970; de Filippo 1970; Penwill 1975, esp. 59-66; Bradley 2000.

${ }^{62}$ See Holzberg 1995; also Fusillo 1999, 61 for a list of examples of that usage from earlier scholarship, whose approach he rejects.

${ }^{63}$ See Millar 1981; also Mattiacci 2001, 843-845. 
aspects of the body, can often have a disconcerting, defamiliarising effect, rather than contributing to an impression of realism. Such representations gain their power precisely by their ability to undermine and unsettle any sense of the naturalness of the way we experience our bodies in day-to-day life. ${ }^{64}$

Lucius' encounter with landscape is a case in point, in the sense that it draws attention to alienness of his own body. Often he seems to be struggling to find exactly the right way of describing these peculiar experiences: the image of the 'pit or window' in his skin from 7,17,4 is an extreme but in some ways typical example. The encounter with landscapes makes him experience his body in unfamiliar, unsettling almost dream-like ways. The defamiliarising effect is also linked with ideas of status. Lucius' uncomfortable, bewildered awareness of his own body and its vulnerability is closely linked with his drop in status, from elite to non-elite, from human to animal (that latter fall being conceptualised as equivalent to the fall from free to slave).$^{65}$ And it is hardly surprising that this drop in status is dramatized through the confrontation with harsh and uncivilized terrain. Wild landscapes - and particularly mountain landscapes - were widely viewed as places for bandits and outcasts who stood apart from normal human culture, and for prodigies who overturned the normal rules of the natural world, as Lucius does in his metamorphosed state. ${ }^{66}$

Lucius' perception of the physicality of landscape in Books 1-10 thus has an air of unreality hanging over it, even when it pays attention to the gritty details of corporeal experience. In the process it plays a key part in the dynamic traced by Nancy Shumate, which I have discussed already. The world of Books 1-10, she suggests, is 'a world characterized by a gradual disintegration of the categories devised to organise its parts into a tidy and meaningful whole. Lucius' environment is one that is radically defamiliarized by changes that rupture its previous unity; it is marked by every kind of instability. His world is one where matter itself is unstable and where familiar ontological and cultural categories - death and life, human and animal, male and female, for example - merge unpredictably into one another' ${ }^{67}$ The defamiliarising quality of Apuleius' highly physical descriptions of landscape in Books 1-10 where even the boundaries between living bodies and inert mud and rock are

${ }^{64}$ Cf. Rimell 2002, 13-15 and 123-124 on Petronius, criticising Auerbach 1953 and others for too straightforwardly applying the vocabulary of realism to the Satyrica; cf. Morales 2004, 128-130 on the way in which Achilles Tatius' descriptions of the physicality of emotional reactions are so detailed that they block any sense of realism, having instead an alienating effect.

${ }^{65}$ Cf. Gianotti 1995; Bradley 2000, esp. 114.

${ }^{66}$ See Trinquier 1999, 262-267; Buxton 1994, 81-96.

${ }^{67}$ Shumate 1996, 35. 
not secure - makes a significant contribution to that portrayal of unstable reality.

\section{Books 10-11}

Book 11 changes everything. The strange landscape experiences of Books 110 - which are both excessively rhetorical and excessively physical at the same time - are banished from the novel together with the other aspects of Lucius' former self, replaced by the higher realities Lucius claims to perceive (albeit, we might suspect, with a degree of self-delusion even here) through his devotion to Isis. In this final section I want to look closely at some of the key passages which make that shift clear.

At 10,29, Lucius is led inside the arena. As he waits, he watches a mime performance of the judgement of Paris which takes place on a stage-set version of Mount Ida, described in intricate detail. ${ }^{68}$ Even more so than for the other mountains of Books 1-10, Apuleius goes out of his way to stress its artificial character:

There was a wooden mountain constructed with lofty workmanship (sublimi instructus fabrica) on the model of that famous mountain which the poet Homer sang of, Mount Ida. It was planted with greenery and living trees, pouring out river water from a spring, made by the hands of the craftsman, on the highest summit. $(10,30,1)$

The themes of fabrication are deeply ingrained here. ${ }^{69}$ The mountain is literally brought alive through the hands of the artificer, through the living plants and trees which grow on it. And its fake, theatrical quality is pointed up all the more prominently at the end of Lucius' description, once the mime has finished:

Then from the highest summit of the mountain, through a hidden pipe, saffron dissolved in wine bursts up high into the air, and falling to the ground, scattering, it rains down on the goats who are pasturing all around with a sweet-smelling shower, until, dyed to a greater beauty, they swap

${ }^{68}$ Oddly not discussed by de Biasi 1990.

${ }^{69}$ See Zimmerman 1993, 148. 
their natural whiteness for a yellow colour. And then, when the whole theatre was filled with a pleasant fragrance, a chasm in the earth swallowed up the wooden mountain. $(10,34,2)$

Here, we see a literalised version of the Golden Age of Virgil Eclogues 4. The sheep become coloured by saffron, but through human, theatrical ingenuity, rather than the workings of nature. ${ }^{70}$ The juxtaposition of that allusion with two distinct references to moralising discussions of theatricality in Seneca only points up the theme of artificial fabrication all the more. ${ }^{71}$

My argument here is that the wooden mountain stands broadly speaking for all the other extravagant, theatrical landscapes Lucius has moved through in his travels. Its similarity with the mountain which houses the robbers' hideout in 4,6 helps to cement that association: for example, the Mount Ida of the arena is described as 'pouring out river water from a spring on the highest summit' (summo cacumine ... fonte manante fluviales aquas eliquans) $(10,30,1)$, in much the same way as the mountain of the bandits ('from the highest peak a spring gushed down'; de summo vertice fons affluens $4,6,4){ }^{72}$ Its character as a stage set is also surely significant: it stands, I suggest, for the way in which Lucius (although he may not be aware of it at the time) is about to discard the world of artifice and illusion he has been in thrall to up till now. Here, with Lucius on the brink of his conversion, the text says goodbye to theatricality, and indeed to theatrical landscapes, sweeping them into oblivion (along with the sensual, voyeuristic pleasures of the 'earthly Venus' which are given such prominence in the description of the dance itself). ${ }^{73}$ To my knowledge that fairly obvious point has gone more or less unnoticed in recent Apuleius scholarship.

It is striking, too, that this mountain, unlike all of the others we have encountered so far in the work, is described in strikingly pleasant terms. Gone now is the language of fearful precipices and rocky paths. ${ }^{74}$ It is as though Apuleius is prompting us as readers, in the moment leading up to the conversion scene, to step back from the association of landscape with suffering and to see it for what it really is - as a stage-set, a prop of the sublunary world of illusion which Lucius will be freed from by his forthcoming devotion to Isis.

\footnotetext{
70 See Zimmerman 2000, 404.

${ }^{71}$ See Finkelpearl 1991, 231-232.

72 See Zimmerman 1993, 146, n.9; Krabbe 2003, 96.

${ }^{73}$ Cf. Schlam 1970, 484-485; Zimmerman 1993, 159-161; Merlier-Espenel 1999, 171-172; Finkelpearl 1991, esp. 225-226.

${ }^{74}$ See Zimmerman 2000, 367; cf. Krabbe 2003, 95 and 109.
} 
In Book 11 mountain landscape and mountain imagery disappear abruptly from view, along with the frequent descriptions of travel by road. ${ }^{75}$ They are replaced by new images of water and the sea. Admittedly there is a fair amount of water imagery sprinkled through Books 1-10, but in contrast with the water of Book 11 it usually involves rivers rather than the sea, and water which is dangerous and frightening rather calm. ${ }^{76}$ In 11,1 , Lucius, after his escape from the arena, bathes on the beach at Cenchreae in order to purify himself. In 11,3, he sees a vision of the divine face of the goddess Isis rising from the sea. In 11,7 , having sprinkled himself with sea water, he makes his way to the festival of Isis, and admires the sea, now lapping calmly against the shore after a storm. After his retransformation the water imagery persists: for example, another bath and purificatory sprinkling in 11,23 , and a journey by sea to Rome in 11,26 .

Mountains in Book 11 are marked above all by their absence, or, in the few passages where they do intrude, by their difference from the mountains of Books 1-10. In 11,13, for example, at the moment of Lucius' transformation back into human form we see a reversal of the earlier hint that Lucius has experienced his body as a kind of landscape, hard and lapidary: the long list of changes to his body includes the detail that 'my lofty neck shrank (cervix procera cohibetur $)^{77}$...my rock-like teeth went back to their human smallness' (dentes saxei redeunt ad humanam minutiem)' $(11,13,5)$. In 11,25, Lucius' emotional prayer of thanksgiving to Isis includes a celebration of her powers over nature: 'The birds travelling in the sky are in awe of your majesty, the beasts wandering on the mountains, the snakes hiding in the ground, and the monsters swimming in the sea' $(11,25,3-4)$. Lucius is now able to view his earlier experience - as 'a beast wandering on the mountains' - with a sense of detachment which is utterly different from his own suffering immersion in mountainous landscape in Books 1-10, and to see with hindsight what he had been blind to before, that all of the world is imbued with the power of Isis. ${ }^{78}$

${ }^{75}$ See Zimmerman 2002, 80-81.

${ }^{76}$ See Nethercut 1968, 111-113; Krabbe 2003, 473-519; Frangoulidis 2008, 217-232.

${ }^{77} \mathrm{Cf}$. 6,14 for procerus applied to a mountain.

${ }^{78}$ Krabbe 2003, 96-98 points out that many of the mountain images of Books 1-10 are transformed in Book 11 to other uses: e.g. the 'wooden platform' (tribunal ligneum) of 11,24,2 echoes the wooden mountain of 10,30-34, and the word ingum, used repeatedly of mountain ridges in Books 1-10 is now used to describe the 'yoke' of servitude to Isis, willingly accepted by Lucius (11,15,5 and 11,30,1); see also van Mal-Maeder 1997b, 97-98 on the way in which Isis' control over the world stands as a superior equivalent to the magic of Meroe, who similarly exercises control over landscape in 1,8; cf. Frangoulidis 2008, 193195. 
One other particularly important passage, finally, is the speech given by the priest of Isis in the moments after Lucius' re-metamorphosis: 'on the slippery path of vigorous youth (lubrico virentis aetatulae) you slid into servile pleasures and gained the perverse reward of your unfortunate curiosity'. $(11,15,1)$ 'At once', Lucius tells us, 'I joined the ceremonial procession and walked along accompanying the shrine' $(11,16,2)$. Looking back at Books 1-10 with this passage in mind we can see that the harsh and slippery roads Lucius has travelled on ${ }^{79}$ are among other things literalised versions of the metaphorical slippery path the priest draws attention to here ${ }^{80}$ Here Lucius is finally in a position, if he pays attention to the priest, to step back from his earlier concern with bodily discomfort, and to understand landscape in a more sophisticated, metaphorical fashion thanks to his newly acquired religious knowledge. The disappearance of slippery roads in Book 11 is also an emblem of Lucius' move from the paths of error to the straight road of righteousness. It is no accident that we see Lucius, immediately after this speech, joining the straight and orderly procession of the goddess, an experience of walking utterly unlike what he has been through in the novel up till now.

\section{Conclusions}

Apuleius' portrayal of landscape, I have argued, has a degree of complexity and sophistication which goes beyond most other examples in classical literature. It offers a striking counter-example to the widespread tendency to assume that classical landscape depiction is nearly always dependent upon stylised rhetorical and poetic clichés. I have also argued, more specifically, that Apuleius' remarkable portrayal of landscape plays a major role in his representation of reality in the Metamorphoses. The landscapes of Books 1-10 are marked out both by their highly rhetorical, stereotyped character and also at the same time by their insistent physicality, which impinges painfully on the novel's human and asinine bodies. Both of those qualities, paradoxically, are signs of the limitation of Lucius' experience of 'reality' in Books 1-10: he is mired in a world of illusion and self-delusion, a world where it is almost impossible to see beyond his bodily appetites and discomforts. It is only with the intervention of Isis that those limitations - at least according to Lucius' own retrospective account - are swept away from view. With them disappear the

\footnotetext{
${ }^{79}$ See Krabbe 2003, 102-105 for a full survey of the word lubricus and related vocabulary in the novel.

${ }^{80}$ Cf. Zimmerman 2002, 87-89; Keulen 2007, 98.
} 
extravagant and threatening mountain landscapes we have become so familiar with in all that has gone before.

\section{Bibliography}

Auerbach, E. 1953. Mimesis: The Representation of Reality in Western Literature (tr. W.R. Trask; first published in German in 1946), Princeton: Princeton University Press.

Bakhtin, M.M. 1981. The Dialogic Imagination: Four Essays by M.M. Bakhtin (edited by M. Holquist; translated by C. Emerson and M. Holquist), Austin: University of Texas Press.

Bradley, K.R. 2000. 'Animalizing the slave: the truth of fiction', JRS 90, 110-125.

Buxton, R. 1994. Imaginary Greece: The Contexts of Mythology, Cambridge: Cambridge University Press.

De Biasi, L. 1990. 'Le descrizioni del paesaggio naturale nelle opere di Apuleio. Aspetti letterari', MAT 14, 199-264.

De Filippo, J.G. 1970. 'Curiositas and the Platonism of Apuleius' Golden Ass', AJPh 111, 471492.

De Jong, I.J.F. 2001. 'The prologue as a pseudo-dialogue and the identity of its (main) speaker', in: A. Kahane, A. Laird (eds.) A Companion to the Prologue of Apuleius' Metamorphoses, Oxford: Oxford University Press, 201-212.

Edwards, M. 1992. 'The tale of Cupid and Psyche', ZPE 94, 77-94.

Elsner, J., Rubiés, J.-P. 1999. 'Introduction', in: J. Elsner, J.-P. Rubiés (eds.), Voyages and Visions: Towards a Cultural History of Travel, London: Reaktion Books, 1-56.

Fick, N. 1991. 'Ville et campagne dans les Métamorphoses d'Apulée', RBPh 69, 110-130.

Finkelpearl, E. 1991. 'The judgement of Lucius: Apuleius' Metamorphoses 10.29-34', CA 10, 221-236.

Frangoulidis, S. 2008. Witches, Isis and Narrative: Approaches to Magic in Apuleius' Metamorphoses, Berlin, New York: Walter de Gruyter.

Fusillo, M. 1999. 'The conflict of emotions: a topos in the Greek erotic novel', in: S. Swain (ed.), Oxford Readings in the Greek Novel, Oxford: Oxford University Press, 60-82 (first published in French in 1990).

Gianotti, G.F. 1995. 'In viaggio con l'asino', in: F. Rosa, F. Zambon (eds.), Pothos: il viaggio, la nostalgia, Trento: Dipartimento di scienze filologiche e storiche, 107-132.

Graverini, L. 2002. 'Corinth, Rome and Africa: a cultural background for the tale of the ass', in: Paschalis, Frangoulidis (eds.), 58-77.

Hall, E. 1995. 'The ass with double vision', in: D. Margolies, M. Ioannou (eds.) Heart of the Heartless World: Essays in Cultural Resistance in Memory of Margot Heineman, London, Boulder: Pluto Press, 47-59.

Harrison, S.J. 2000. Apuleius: A Latin Sophist, Oxford, New York: Oxford University Press.

- 2002. 'Literary topography in Apuleius' Metamorphoses', in: Paschalis, Frangoulidis (eds.), 40-57.

Hijmans, B.L. et al. 1977. Apuleius Madaurensis Metamorphoses: Book IV 1-27, Text, Introduction and Commentary, Groningen: Bouma.

Holzberg, N. 1995. The Ancient Novel: An Introduction (translated by C. Jackson-Holzberg; first published in German in 1986), London: Routledge.

Kenney, E.J. 1990. 'Psyche and her mysterious husband', in: D.A. Russell (ed.), Antonine Literature, Oxford: Oxford University Press, 175-198. 
Keulen, W.H. 2007. Apuleius Madaurensis Metamorphoses: Book I, Text, Introduction and Commentary, Groningen: Egbert Forsten.

Keuls, E. 1974. 'Une cible de la satire: le locus amoenus', LEC 42, 265-275.

Krabbe, J.K. 2003. Lusus iste: Apuleius' Metamorphoses, Dallas, Lanham, Boulder, New York, London: University Press of America.

MacFarlane, R. 2003. Mountains of the Mind: The History of a Fascination, London: Granta Books.

Mattiacci, S. 2001. 'Riscritture apuleiane del locus amoenus', in: S. Bianchetti et al. (eds.), POIKILMA: Studi in onore di Michele R. Cataudella, La Spezia: Agorà edizioni, 843-859.

Merlier-Espenel, V. 1999. 'Les représentations de la nature dans les Métamorphoses d'Apulée', in: C. Cusset (ed.), La nature et ses représentations dans l'antiquité, Paris: Centre national de documentation pédagogique, 157-172.

Millar, F. 1981. 'The world of the Golden Ass', JRS 71, 63-75.

Morales, H. 2004. Vision and Narrative in Achilles Tatius' Leucippe and Clitophon, Cambridge: Cambridge University Press.

Nethercut, W.R. 1968. 'Apuleius' literary art: resonance and depth in the Metamorphoses', CJ 64, 110-119.

- 1969. 'Apuleius' Metamorphoses: the journey', Agon 3, 97-134.

Nicholson, M. 1959. Mountain Gloom and Mountain Glory: The Development of the Aesthetics of the Infinite, Ithaca: Cornell University Press (reprinted 1997, Seattle: University of Washington Press).

O'Brien, M. 2002. Apuleius' Debt to Plato in the Metamorphoses, Lewiston, Queenston, Lampeter: Edwin Mellen Press.

Paschalis, M. 2002. 'Reading space: a re-examination of Apuleian ekphrasis', in: Paschalis, Frangoulidis (eds), 132-142.

Paschalis, M., Frangoulidis, S. (eds.). 2002. Space in the Ancient Novel, Ancient Narrative Supplementum 1, Groningen: Barkhuis Publishing \& Groningen University Library.

Penwill, J. 1975. 'Slavish pleasures and profitless curiosity: fall and redemption in Apuleius' Metamorphoses', Ramus 69, 49-82.

- 1990. 'Ambages reciprocae: reviewing Apuleius' Metamorphoses', Ramus 19, 1-25.

Rimell, V. 2002. Petronius and the Anatomy of Fiction, Cambridge: Cambridge University Press.

Schiesaro, A. 1985. 'Il locus horridus nelle Metamorfosi di Apuleio, Met. IV, 28-35', Maia 37, 211-223.

Schlam, C. 1970. 'Platonica in the Metamorphoses of Apuleius', TAPhA 101, 477-487.

Shumate, N. 1996. Crisis and Conversion in Apuleius' Metamorphoses, Ann Arbor: University of Michigan Press.

Slater, N.W. 2002. 'Space and displacement in Apuleius', in: Paschalis, Frangoulidis (eds.), 161-176.

Smith, W. 1998. 'Cupid and Psyche tale: mirror of the novel', in: M. Zimmerman et al. (eds.), Aspects of Apuleius' Golden Ass Volume II: Cupid and Psyche, Groningen: Egbert Forsten, 69-82.

Trinquier, J. 1999. 'Le motif du repaire des brigands et le topos du locus horridus: Apulée, Metamorphoses, IV, 6', RPh 73, 257-277.

Van Mal-Maeder, D. 1997a. 'Descriptions et descripteurs: mais qui décrit dans les Métamorphoses d'Apulée?', in: M. Picone, B. Zimmermann (eds.), Der antike Roman und seine mittelalterliche Rezeption, Basel, Boston, Berlin: Birkhäuser Verlag, 171-201. 
- 1997b. 'Lector intende: laetaberis: the enigma of the last book of Apuleius' Metamorphoses', GCN 8, 87-118.

- 2001. Apuleius Madaurensis Metamorphoses: Livre II, Texte, Introduction et Commentaire, Groningen: Egbert Forsten.

Walsh, P.G. 1970. The Roman Novel. The 'Satyricon' of Petronius and the 'Metamorphoses' of Apuleius, Cambridge: Cambridge University Press.

Webb, R. 2009. Ekphrasis, Imagination and Persuasion in Ancient Rhetorical Practice and Theory, Aldershot, Burlington, VT: Ashgate.

Wylie, J. 2007. Landscape, London, New York: Routledge.

Zimmerman, M. 1993. 'Narrative judgement and reader response in Apuleius' Metamorphoses 10,29-34: the pantomime of the judgement of Paris', GCN 5, 143-161.

- 2000. Apuleius Madaurensis Metamorphoses: Book X, Text, Introduction and Commentary, Groningen: Egbert Forsten.

- 2002. 'On the road in Apuleius' Metamorphoses', in: Paschalis, Frangoulidis (eds.), 7897. 